\title{
Screening travellers to high-endemic countries for infection with Mycobacterium tuberculosis using interferon gamma release assay; a prospective study
}

Floor Elfrink ${ }^{1,2}$, Anneke van den Hoek ${ }^{1,3}$, Marlies E Mensen ${ }^{1}$ and Gerard JB Sonder ${ }^{1,2,3^{*}}$

\begin{abstract}
Background: International travel from low-incidence to high-incidence countries for tuberculosis (TB) is regarded as a risk factor for acquiring TB infection. In this prospective study among long-term travellers we examined the incidence of TB infection using Interferon gamma release assay (IGRA) test and compared these data with results from a visit to the TB department to which all long-term travellers were routinely referred.

Methods: Immunocompetent adults, travelling for 13-52 weeks to TB-endemic countries, donated blood pre- and post-travel for IGRA. The pre-travel IGRA was only tested in case of a positive IGRA post-travel. Results from their visit(s) to the TB department for TST pre- and post-travel were collected and compared with study results.

Results: We found two IGRA conversions in a group of 516 travellers, resulting in an attack rate (AR) of $0.4 \%$ (95\% Cl: 0.5 - 13.9) and an incidence rate (IR) of 0.85 per 1000 person-months (95\% Cl: 0.1-3.1).

We found 5 tuberculin skin test (TST) conversions, resulting in AR of 1.9\% (5/261; 95\% Cl: $0.6-4.4)$ and an IR of 4.26 per 1000 person-months (95\% Cl: 1.38- 9.94). In our study these converters all had a negative IGRA. One traveller however, who was retested later at the TB department due to a positive TST, then appeared to have seroconverted.

Conclusions: The risk of long-term travellers among our study population acquiring TB infection is low. We conclude that post-travel IGRA alone could be used for screening for TB infection among long-term travellers to high-endemic TB countries, but preferably not earlier than 8 weeks after return. One might even argue that IGRA testing should be limited to only those travellers who are going to work in a medical setting. A person with a positive IGRA should be referred to a TB physician for further evaluation.
\end{abstract}

\section{Background}

International travel from low-incidence to high-incidence countries for tuberculosis (TB) is regarded as a risk factor for acquiring TB infection. This risk increases with the time spent in a high-incidence country and travellers' participation in high-risk activities such as working in healthcare settings $[1,2]$.

A latent TB infection (LTBI) can progress to active, infectious disease. For the majority, the estimated lifetime

\footnotetext{
* Correspondence: gsonder@ggd.amsterdam.nl

'Department of Infectious Diseases, Public Health Service (GGD), Nieuwe Achtergracht 100, 1018 WT Amsterdam, the Netherlands

${ }^{2}$ National Coordination Centre for Traveller's Health Advice (LCR), Amsterdam, the Netherlands

Full list of author information is available at the end of the article
}

risk of developing active TB for individuals with an LTBI is $10 \%$ within the first years after infection $[3,4]$. Identifying and treating people with (recently acquired) LTBI is important in disease control, especially in countries with a low incidence of TB.

For a long time the only available test for detecting Mycobacterium tuberculosis infection was the tuberculin skin test (TST). TST has several limitations: intraobserver variation in reading the results, limited specificity in BCG-vaccinated individuals, false-positive results due to non-tuberculous mycobacteria, and a boosting phenomenon if TST is repeated. In addition, TST must be read after three days, requiring a second healthcare visit, thus resulting in poor compliance [5]. 
Interferon gamma release assay (IGRA), commercially available since 2005, is an in vitro T-cell based test which quantifies the immune response of T-cells to in vitro exposure to antigens of $M$. tuberculosis, other than those used in BCG vaccination [6]. A positive test result suggests $M$. tuberculosis infection. Compared to TST, IGRA has several advantages: only a single patient visit is required, results can be available within 24 hours, and there is no cross reaction with the BCG vaccine or with most non-tuberculous mycobacteria.

A gold standard for diagnosis of TB infection is absent, hindering good evaluation of the tests. A review in 2008 investigating the role of IGRAs in screening of travellers, showed too many limitations to come to a recommendation. Thus, the advantage of screening travellers by use of IGRA remains unclear [4].

A previous Dutch study conducted in 1994-1996 demonstrated that the incidence of TB for long-term travellers (3-12 months) based on TST conversions approaches that of the local population when travelling to high-incidence countries [1]. In this prospective study among long-term travellers we examined the incidence of TB infection using IGRA and we compared IGRA results with data from the TB department to which long-term travellers were referred according to national traveller guidelines.

\section{Methods}

\section{Study population}

This study was part of a larger prospective mono-centre study among persons attending the Public Health Service (PHS) Amsterdam travel clinic in the Department of Infectious Diseases [7]. All immunocompetent persons $\geq 18$ years and of Dutch or other Western ethnicity were eligible if they were planning to travel to (sub)tropical countries for 13-52 weeks. For this sub-study, only participants who spent $\geq 13$ weeks in a TB-endemic country, defined as countries with an annual TB incidence of $>50 / 100,000$, were included [8].

Before departure, a standard questionnaire was used to collect data on socio-demographics, BCG-vaccination history, travel history (indicated as cumulative time spent in Asia, Latin America, or Africa during lifetime), and travel purpose. The study protocol was approved by the Medical Ethics Committee of the Academic Medical Center Amsterdam. Participants were included after providing written informed consent.

Blood samples were taken before and 2-6 weeks after travel.

For IGRA the QuantiFERON-TB Gold (Cellestis Limited, Victoria, Australia) was performed following the manufacturer's instruction and was considered positive if $\geq$ cut-off point of $0.35 \mathrm{IU} / \mathrm{ml}$. All post-travel samples were tested. Due to financial constraints only in case of a positive posttravel sample the pre-travel sample was tested, which had been stored at $-80^{\circ} \mathrm{C}$. Positive post-travel samples with negative pre-travel samples were considered conversions.

TST was performed according to the Mantoux method with $0.1 \mathrm{ml}$ Purified Protein Derivative (PPD) RT23 (Statens Serum Institute, Copenhagen, Denmark). Experienced medical staff of the TB department read the induration between 72 hours and 96 hours. Differences in induration of $\geq 10 \mathrm{~mm}$ between pre- and post-travel TST were considered conversions if pre-travel TST was $<10 \mathrm{~mm}$.

Although TST is recommended $\geq 8$ weeks post-travel, participants in this study were referred to the TB department for a TST at the same time as the post-travel study visit. At the TB department, they were either tested and/ or asked to return 8 weeks after travel.

Data analysis was performed with SPSS version 19.0.0.1 (2010, IBM, Somers, USA).

Chi-square tests were used to evaluate predictive value for TST or IGRA conversion. Tested characteristics included: age, sex, BCG, reason for travel, healthcare work, travel duration, and primary destination.

Incidences were expressed as the rate based on the person-time spent in endemic countries. Person-time denominators for converters were divided in half, since infection was assumed to have occurred halfway during travel. For travellers with a negative TST post-travel and an unknown TST pre-travel, we assumed they were also negative pre-travel. Confidence intervals for both the attack- and incidence rates have been calculated.

\section{Results}

\section{Study population}

Between December 2008 and September 2011, 684 persons intending to travel to (sub) tropical countries for 1352 weeks provided informed consent. Of these, 168 were excluded upon completion of the study (Figure 1): 42 travellers had their travel arrangements changed, 80 had an itinerary that did not include TB-endemic countries for $\geq 13$ weeks, 2 were excluded because blood samples failed, 6 were excluded because they received treatment for TB at the time of study $(n=3)$ or had a positive TST in the past for which treatment had been given $(n=3)$, and 38 were lost to follow-up. Resulting in a total of 516 travellers included in this study.

\section{Characteristics}

Characteristics are summarised in Table 1. The median age was 25 years and 35\% were female. Mean travel duration was 22 weeks. Travel purpose was tourism for $62 \%$ of participants, work for $36 \%$, and $2 \%$ were visiting friends or relatives (VFR). Of the 187 persons travelling for (volunteer) work, 20 reported work in a medical setting.

South East Asia was the primary destination for 37\%, South America for 23\%, and Sub-Saharan Africa for 22\%. 


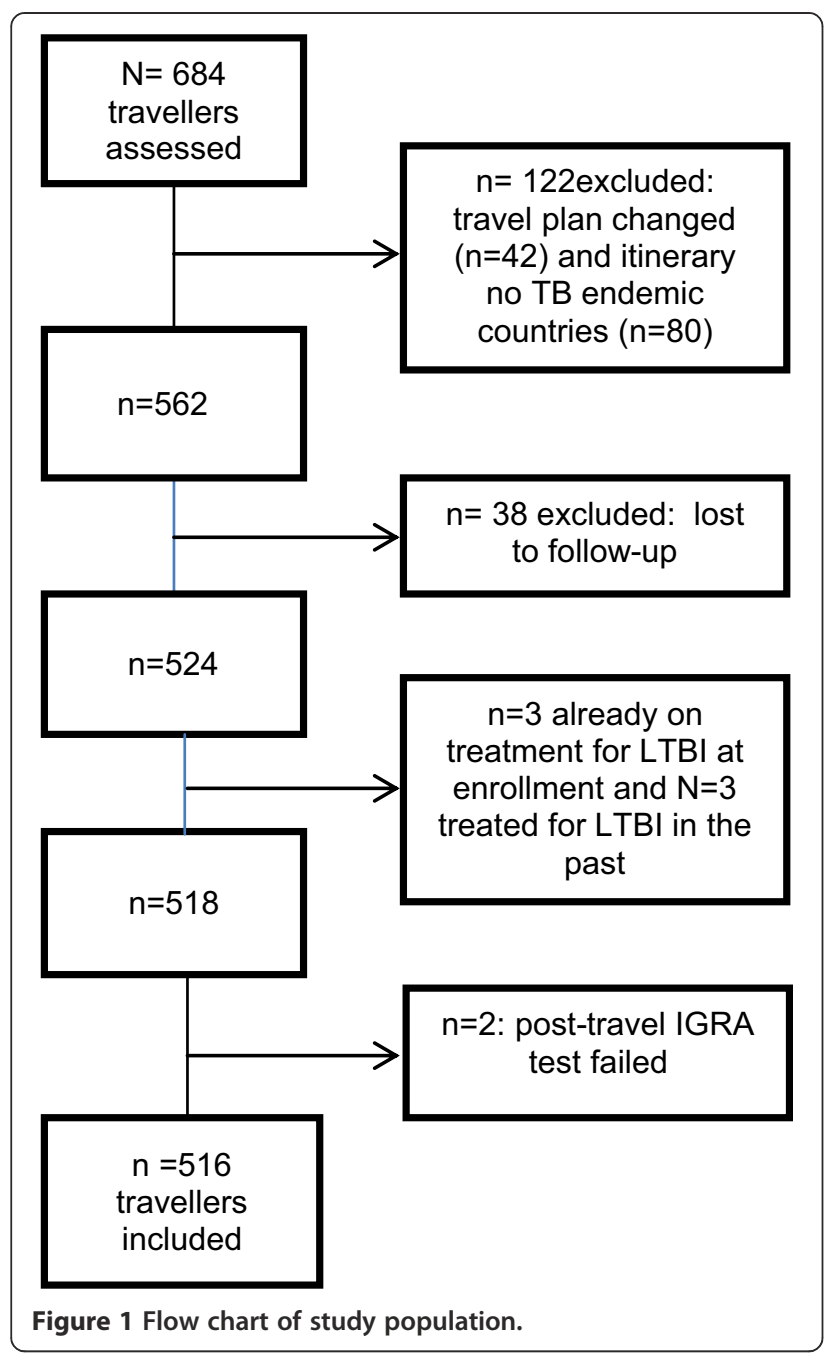

Mean interval between return from travel, blood donation and TST was 30 and 50 days respectively.

\section{Results IGRA}

Five of all 516 participants had a positive post-travel IGRA. Of those, three pre-travel samples were already positive, yielding two conversions (Table 2) and resulting in an attack rate of $0.4 \%(2 / 513 ; 95 \%$ CI: $0.5-13.9)$ and an incidence rate of 0.85 per 1000 person-months (95\% CI: $0.1-3.1$ ). Of the tested characteristics, no risk factors predictive for IGRA conversions were found. One traveller, number 7 (Table 2), was initially negative but was tested again later due to a positive TST and appeared then to have seroconverted.

\section{Results TST}

Of the 516 inclusions, 43 had been BCG-vaccinated. Of the 473 unvaccinated travellers eligible for post-travel TST, 3 had a TST pre-travel result of $\geq 10 \mathrm{~mm}$ and 7 travellers received a BCG-vaccine pre-travel. After excluding
Table 1 Characteristics of 516 travelers to TB-endemic countries who attended a Dutch travel clinic for pre-travel health advice; December 2008-September 2011

\begin{tabular}{|c|c|c|c|}
\hline & & Total & $\%$ \\
\hline Age & $\begin{array}{l}\text { Median, years } \\
\text { (interquartile range) }\end{array}$ & 25.0 & $(23-30)$ \\
\hline \multirow[t]{2}{*}{ Sex } & Female & 336 & 65 \\
\hline & Male & 180 & 35 \\
\hline \multirow[t]{2}{*}{ BCG (before travel) } & No & 473 & 92 \\
\hline & Yes & 43 & 8 \\
\hline \multirow[t]{2}{*}{ Travel history } & Yes & 413 & 80 \\
\hline & No & 103 & 20 \\
\hline \multirow[t]{5}{*}{ Reason for travel } & Tourism & 321 & 62 \\
\hline & Work: non medical setting & 95 & 18 \\
\hline & Work: medical setting & 20 & 4 \\
\hline & Work: unknown setting & 72 & 14 \\
\hline & VFR & 8 & 2 \\
\hline Travel duration & Mean, weeks (SD) & 21,9 & (8.55) \\
\hline \multirow{7}{*}{$\begin{array}{l}\text { Travel destination } \\
\text { primary }\end{array}$} & South East Asia & 190 & 37 \\
\hline & South America & 116 & 23 \\
\hline & Sub-Saharan Africa & 111 & 22 \\
\hline & Asia, South & 50 & 10 \\
\hline & $\begin{array}{l}\text { Caribbean/Central } \\
\text { America }\end{array}$ & 29 & 6 \\
\hline & Asia, other & 19 & 3 \\
\hline & North Africa/Middle East & 1 & 0.2 \\
\hline \multicolumn{4}{|c|}{ Interval between return and blood donation (days) } \\
\hline & Mean (SD) & 29,8 & $(16.0)$ \\
\hline \multicolumn{4}{|c|}{ Interval between return and TST (days) $(n=261)$} \\
\hline & Mean (SD) & 49.8 & (36.8) \\
\hline
\end{tabular}

TB: tuberculosis; SD: standard deviation.

these 10 participants, 64\% (295/463) complied with a post-travel TST, however 34 did not return to let their TST result be read.

Of the remaining 261 post-travel TST, 8 were considered positive. Of these, pre-travel test results were unknown for 3 (non-compliance), resulting in 5 demonstrated and 3 potential conversions (Table 2).

Of the 253 negative post-travel TST 197 had a known negative TST pre-travel. Assuming that the remaining 56 were also negative pre-travel, we found an attack rate (AR) of 1.9\% (5/261; 95\% CI: 0.6 - 4.4) for demonstrated TST conversions and an incidence rate (IR) of 4.26 per 1000 person-months (95\% CI: 1.38- 9.94).

When including potential conversions, we found an AR of 3.1\% (8/261) and an IR of 6.76 per 1000 personmonths (95\% CI: 2.9- 13.3).

None of the tested characteristics were predictive for TST conversion. 
Table 2 Positive post-travel IGRA* and TST** results in a cohort of 516 travellers to TB-endemic countries, December 2008-September 2011

\begin{tabular}{|c|c|c|c|c|c|c|c|c|c|c|c|c|c|c|c|}
\hline \multicolumn{3}{|c|}{ Traveller } & \multicolumn{4}{|c|}{ Travel } & \multicolumn{4}{|c|}{ IGRA (IU/ml) } & \multicolumn{4}{|c|}{ TST (mm) } & \multirow[t]{2}{*}{ Follow-up at TB department } \\
\hline & $\begin{array}{l}\text { Age range } \\
\text { (y) }\end{array}$ & BCG & $\begin{array}{l}\text { Travel } \\
\text { history }\end{array}$ & Reason & Destination & $\begin{array}{l}\text { Duration } \\
\text { (days) }\end{array}$ & $\begin{array}{l}\text { Pre- } \\
\text { travel }\end{array}$ & $\begin{array}{l}\text { Post- } \\
\text { travel }\end{array}$ & $\begin{array}{l}\text { Interval } \\
\text { return and } \\
\text { IGRA (days) }\end{array}$ & Conversion & $\begin{array}{l}\text { Pre- } \\
\text { travel }\end{array}$ & $\begin{array}{l}\text { Post- } \\
\text { travel }\end{array}$ & $\begin{array}{l}\text { Interval } \\
\text { return and } \\
\text { TST (days) }\end{array}$ & Conversion & \\
\hline 1 & $31-35$ & no & $\begin{array}{l}\text { Asia: } 3 w \text { Latin } \\
\text { America: } 4 w\end{array}$ & $\begin{array}{l}\text { non medical } \\
\text { work }\end{array}$ & SE Asia & 365 & $-0,05$ & 1.15 & 29 & yes & nt & 8 & 39 & no & $\begin{array}{l}\text { Volunteer work, non-medical. } \\
\text { TST performed in 2000: } \\
0 \text { mm. Started preventive } \\
\text { treatment } 43 \text { days post travel. }\end{array}$ \\
\hline 2 & $26-30$ & no & Africa: $1 \mathrm{w}$ & tourism & SE Asia & 172 & $-0,03$ & 0,56 & 25 & yes & $\mathrm{nt}$ & 2 & 37 & no & $\begin{array}{c}\text { IGRA repeated } 85 \text { days post travel: } \\
0.21 \mathrm{IU} / \mathrm{ml} \text {. No preventive treatment } \\
\text { was started. }\end{array}$ \\
\hline 3 & $26-30$ & no & no & $\begin{array}{l}\text { non medical } \\
\text { work }\end{array}$ & SE Asia & 150 & $\mathrm{nt}$ & $-0,01$ & 27 & no & 2 & 13 & 27 & yes & $\begin{array}{l}\text { IGRA repeated } 55 \text { days post travel: } \\
0.002 \mathrm{IU} / \mathrm{ml} \text {. According to Dutch } \\
\text { guidelines: no preventive treatment } \\
\text { was started since IGRA was negative. }\end{array}$ \\
\hline 4 & $41-45$ & no & $\begin{array}{l}\text { Asia: } 3 \mathrm{mo} \\
\text { Africa: } 5 \mathrm{w}\end{array}$ & $\begin{array}{l}\text { non medical } \\
\text { work }\end{array}$ & SE Asia & 356 & $\mathrm{nt}$ & 0,02 & 28 & no & 2 & 15 & 112 & yes & No follow-up. \\
\hline 5 & $18-20$ & no & no & tourism & $\begin{array}{l}\text { SE Asia/ } \\
\text { East Asia }\end{array}$ & 93 & $\mathrm{nt}$ & 0,04 & 38 & no & 0 & 11 & 90 & yes & $\begin{array}{l}\text { No follow-up IGRA. X-ray } 94 \text { days } \\
\text { post travel showed no abnormalities; } \\
\text { no preventive treatment. }\end{array}$ \\
\hline 6 & $36-40$ & no & $\begin{array}{l}\text { Asia: } 2 \text { mo } \\
\text { Latin America: } \\
\quad 9 \text { mo }\end{array}$ & tourism & South Asia & 180 & $\mathrm{nt}$ & $-0,05$ & 42 & no & 0 & 10 & 63 & yes & $\begin{array}{l}\text { No follow-up. No preventive } \\
\text { treatment. }\end{array}$ \\
\hline 7 & $21-25$ & no & Africa: 6 w & $\begin{array}{l}\text { medical } \\
\text { setting }\end{array}$ & $\begin{array}{l}\text { Sub-Sahara } \\
\text { Africa }\end{array}$ & 118 & $\mathrm{nt}$ & 0,11 & 18 & no & 0 & 10 & 79 & yes & $\begin{array}{c}\text { Medical student in a hospital in } \\
\text { East-Africa for } 3 \text { months. IGRA } \\
\text { repeated } 79 \text { days post travel: } \\
7.47 \mathrm{IU} / \mathrm{ml} \text {; Preventive therapy } \\
\text { was started. }\end{array}$ \\
\hline 8 & $26-30$ & no & $\begin{array}{l}\text { Asia: } 6 \mathrm{w} \\
\text { Latin America: } \\
5 \mathrm{mo}\end{array}$ & tourism & $\begin{array}{l}\text { Central } \\
\text { America }\end{array}$ & 147 & $\mathrm{nt}$ & $-0,01$ & 20 & no & $\mathrm{nt}$ & 18 & 20 & unknown & $\begin{array}{l}\text { No IGRA follow-up. X thorax } \\
\text { showed no abnormalities. } \\
\text { No preventive treatment. (TST } \\
\text { performed in } 2007 \text { was } 6 \text { mm). }\end{array}$ \\
\hline 9 & $41-45$ & no & $\begin{array}{l}\text { Asia: } 6 \mathrm{mo} \\
\text { Africa: } 1 \mathrm{mo}\end{array}$ & $\begin{array}{l}\text { non medical } \\
\text { work }\end{array}$ & $\begin{array}{l}\text { sub-Sahara } \\
\text { Africa }\end{array}$ & 242 & $\mathrm{nt}$ & $-0,01$ & 51 & no & nt & 11 & 51 & unknown & $\begin{array}{l}\text { No follow-up. According to Dutch } \\
\text { guidelines: no preventive treatment } \\
\text { was started since IGRA was negative. }\end{array}$ \\
\hline 10 & $21-25$ & no & Africa: 10 mo & tourism & $\begin{array}{l}\text { Central } \\
\text { America }\end{array}$ & 214 & nt & 0.00 & 21 & no & nt & 10 & 61 & unknown & $\begin{array}{l}\text { Advised to have IGRA repeated but } \\
\text { no compliance. }\end{array}$ \\
\hline
\end{tabular}

IGRA: interferon gamma release assay; TST: tuberculin skin test; TB: tuberculosis; y: years; w: weeks; mo: months; nt: not tested; *: of all 516 samples tested; **: of all 261 TST results. 


\section{Comparison of IGRA and TST}

Of the 2 travellers with an IGRA conversion, one had a TST of $8 \mathrm{~mm}$ post-travel (unknown pre-travel TST) and the other was negative $(2 \mathrm{~mm})$, tested 39 and 37 days respectively after return (Table 2). The first has been treated for TB infection. The latter had the IGRA test repeated 85 days after return, which was then negative, and was therefore considered not to have TB infection.

All five TST converted individuals and the 3 potential conversions (positive TST post-travel but an unknown pre-travel TST) had a negative post-travel IGRA.

Traveller number 7 , who had worked in a hospital in East-Africa, had a negative IGRA 18 days after return. At the TB department 79 days after return the TST was $10 \mathrm{~mm}$. The IGRA at that time was also positive $(7.47$ $\mathrm{IU} / \mathrm{ml}$ ), and therefore treatment for $\mathrm{TB}$ infection was started. This was considered the only confirmed seroconversion; of the remaining 7 , none were treated for TB infection.

\section{Discussion}

Based on the IGRA test, this prospective study found a low incidence of recent infection with $M$ tuberculosis among long-term immunocompetent travellers to TBendemic countries; an attack rate (AR) of $0.4 \%$ and an incidence rate (IR) of 0.85 per 1000 person-months.

Based on TST conversions, we found an AR of $1.9 \%$ and an IR of 4.3 per 1000 person-months comparable to an AR of $1.8 \%$ and an IR of 3.5 per 1000 person-months in a previous Dutch study, which had an enrolment period from 1994 till 1996 [1].

Results of IGRA and TST were not concordant as has been found in other studies [8-10]. The most likely reason for a positive TST with a negative IGRA, is a false-positive TST due to atypical mycobacteria. Another explanation for this discrepancy in our study could be that occasionally IGRA was tested earlier than TST. Indeed, in one case in our study (traveller 7, Table 2), a traveller with a negative pre-travel TST who worked in a medical setting in East-Africa for 3 months, had a negative IGRA, tested 18 days post travel. Because of the positive TST 11 weeks post travel, IGRA was repeated at the TB control department and turned out to be highly positive $(7.47 \mathrm{IU} / \mathrm{ml})$. This traveller was probably infected in the latter part of his/her stay in East-Africa. This particular case shows that it is important not to perform the IGRA earlier than the TST, which is done at least 8 weeks after return from a TB-endemic country. That this time interval is important is also demonstrated in traveller 2 , who showed a positive IGRA tested 3 weeks post travel and a $5 \mathrm{~mm}$ TST 5 weeks post travel. The IGRA was repeated 55 days after return and appeared to be negative.

As already mentioned in the introduction, there are several disadvantages of TST compared to IGRA of which the poor compliance is an important one [5]. In addition, compliance for TST was poor in this study at only $56 \%$. A single IGRA visit is expected to increase the compliance for screening and a traveller's own GP can ask for an IGRA test, which, in contrast to the TST, means that referral to the TB specialist is not necessary. The estimated high specificity of IGRA for the diagnosis of LTBI in immunocompetent subjects justifies that negative results are considered true negatives. However, a positive IGRA requires a physician's careful risk assessment before deciding to start preventive therapy, which is illustrated by traveller 2 mentioned previously.

The use of IGRA is already known to decrease the number of people that are recommended preventive treatment for TB infection: in the Netherlands adding the IGRA test to the screening protocol (two-step approach of starting with TST, followed by an IGRA if induration of the TST is $\geq 5 \mathrm{~mm}$ ) has led to a decrease of the number of people who are recommended preventive treatment [11].

Evaluation of the TB department's follow-up of travellers with a negative IGRA, performed within the incubation period, and a positive TST showed that in most cases no IGRA retesting had taken place, either because the TB physician found the traveller at low risk for TB infection or due to non-compliance. However, none of the participants was registered in the national TB register by the end of 2013. The only traveller in our study who was considered to have a true conversion and who was treated for TB was one of the 20 travellers who reported to have been working in a medical setting. Therefore one might argue whether testing for TB should be limited to only those travellers with potential exposure by working in a medical setting in TB endemic countries.

\section{Conclusions}

We conclude that the risk of acquiring TB infection in immunocompetent long-term travellers is low. A post-travel IGRA alone could be a useful screening tool for TB infection among long-term travellers to high-endemic TB countries, arguably even limited to only those travellers with potential exposure by working in medical settings, enhancing compliance compared to TST. However, the IGRA test should be performed at least 8 weeks after return. A person with a positive IGRA should be referred to a TB physician for further evaluation.

\section{Competing interests}

The authors declare that they have no competing interests.

\section{Authors' contributions}

FE performed the statistical analyses and wrote the draft manuscript. GS and $\mathrm{AH}$ conceived the idea for the study, designed the project, and provided constructive comments. MM was responsible for TST tests and helped design the project and provided constructive comments. All authors revised and approved the final version. 


\section{Acknowledgements}

This study was conducted within the Sarphati Initiative: Academic Collaborative Centre on Public Health of Noord-Holland and Flevoland, the Netherlands. The Sarphati Initiative is financially supported by the Netherlands Organisation for Health Research and Development (ZonMw; grant number 125010001).

We thank the physicians and nurses of the travel clinic and tuberculosis control department of the Public Health Service Amsterdam for assistance in data collection, in particular Sanne Belderok and Joan Kint.

\section{Author details}

'Department of Infectious Diseases, Public Health Service (GGD), Nieuwe Achtergracht 100, 1018 WT Amsterdam, the Netherlands. ${ }^{2}$ National Coordination Centre for Traveller's Health Advice (LCR), Amsterdam, the Netherlands. ${ }^{3}$ Department of Internal Medicine, Division of Infectious Diseases, Tropical Medicine and AIDS, Amsterdam, the Netherlands.

Received: 5 March 2014 Accepted: 11 September 2014 Published: 23 September 2014

\section{References}

1. Cobelens FG, van Deutekom H, Draayer-Jansen IW, Schepp-Beelen AC, van Gerven PJ, van Kessel RP, Mensen ME: Risk of infection with Mycobacterium tuberculosis in travellers to areas of high tuberculosis endemicity. Lancet 2000, 356(9228):461-465.

2. Johnston VJ, Grant AD: Tuberculosis in travellers. Travel Med Infect Dis 2003, 1:205-212.

3. Cobelens FG, van Deutekom H, Draayer-Jansen IW, Schepp-Beelen AC, van Gerven PJ, van Kessel RP, Mensen ME: Association of tuberculin sensitivity in Dutch adults with history of travel to areas of with a high incidence of tuberculosis. Clin Infect Dis 2001, 33(3):300-304.

4. Ingram PR, Fisher DA, Wilder-Smith A: Latent tuberculosis infection in travelers: is there a role for screening using interferon-gamma release assays? J Travel Med 2009, 16(5):352-356.

5. Cobelens FG, Draayer-Jansen EW, Schepp-Beelen JC, van Gerven PJ, van Kessel RJ, van Deutekom H: [Limited tuberculin screening participation amongst travellers to countries with high tuberculosis incidence; reason to consider BCG vaccination for some travellers]. Ned Tijdschr Geneeskd 2003, 147(12):561-565 [Article in Dutch].

6. Centers for Disease Control and Prevention (CDC): Trends in tuberculosis-United States, 2010. MMWR Morb Mortal Wkly Rep 2011, 60(11):333-337.

7. Whelan J, Belderok SM, van den Hoek A, Sonder GJB: Unprotected casual sex equally common with local and western partners among long-term Dutch travelers to (sub) tropical countries. Sex Transm Dis 2013, 40:797-800.

8. WHO global tuberculosis report. 2013, http://www.who.int/tb/publications/ global_report/en/ (Accessed 13 September 2014).

9. Pai M, Kalantri S, Dheda K: New tools and emerging technologies for the diagnosis of tuberculosis: part I. Latent tuberculosis. Expert Rev Mol Diagn 2006, 6(3):413-422.

10. Pai M, Zwerling A, Menzies D: Systematic review: T-cell-based assays for the diagnosis of latent tuberculosis infection: an update. Ann Intern Med 2008, 149(3):177-184. Epub 2008 Jun 30.

11. Erkens CG, Dinmohamed AG, Kamphorst M, Toumanian S, van Nispen-DobresCu R, Alink M, Oudshoorn N, Mensen M, van den Hof S, Borgdorff M, Verver S: Added value of interferon-gamma release assays in screening for tuberculous infection in the Netherlands. Int J Tuberc Lung Dis. 2014, 18(4):413-420

doi:10.1186/1471-2334-14-515

Cite this article as: Elfrink et al:: Screening travellers to high-endemic countries for infection with Mycobacterium tuberculosis using interferon gamma release assay; a prospective study. BMC Infectious Diseases 2014 14:515.

\section{Submit your next manuscript to BioMed Central and take full advantage of:}

- Convenient online submission

- Thorough peer review

- No space constraints or color figure charges

- Immediate publication on acceptance

- Inclusion in PubMed, CAS, Scopus and Google Scholar

- Research which is freely available for redistribution

Submit your manuscript at www.biomedcentral.com/submit
Biomed Central 